\title{
Characterization, screening, and application of bacteria with probiotic properties isolated from the gut of Labeo calbasu (Hamilton)
}

\author{
Anita Bhatnagar, Oshin Dhillon
}

Received - 27 March 2018/Accepted - 20 November 2019. Published online: 31 December 2019; $\odot$ Inland Fisheries Institute in Olsztyn, Poland Citation: Bhatnagar A., Dhillon O. 2019 - Characterization, screening, and application of bacteria with probiotic properties isolated from the gut of Labeo calbasu (Hamilton) - Fish. Aquat. Life 27: 178-189.

\begin{abstract}
Labeo calbasu is not reared in aquaculture because of the unavailability of proper feed and the risk of infection. The ability of probiotics to promote growth and immunological defense barriers in the gut has led to the use of autochthonous probiotic bacteria. Hence, the present study was conducted to screen potential probiotic bacteria from the gut of L. calbasu and to supplement the same to study the effect on growth and immunity. Strains with probiotic properties were assayed for exogenous enzyme production and identified based on phylogenetic analysis and nucleotide homology. Four of nine isolates showed promising antibacterial activity against Aeromonas hydrophila. The strains survived in relatively low $\mathrm{pH}$ and high bile concentrations and were investigated for hydrophobicity, autoaggregation, and coaggregation. Based on the positive results of this study, the LC1 and LC4 strains (analysed with 16S rRNA gene sequencing and showing similarity with Aneurinibacillus aneurinilyticus and Stenotrophomonas sp.) were further incorporated into diets to explore their probiotic effects on the growth performance and immunity of the fish. Administering the probiotics elevated growth parameters and benefitted the immune system by increasing the phagocytic index and decreasing the mortality rate with exposure to $A$. hydrophila.
\end{abstract}

A. Bhatnagar [ $\left.\Xi^{\circ}\right]$, O. Dhillon

Department of Zoology, Kurukshetra University, Kurukshetra,

136119, Haryana, India

e-mail: anitabhatnagar@gmail.com
Keywords: A. hydrophila, Aneurinibacillus, autochthonous, L. calbasu, probiotics, Stenotrophomonas

\section{Introduction}

Aquaculture is a reliable production method for satisfying the growing global demand for animal protein for human consumption. Success in fish culture requires ensuring quality feed, a good environment, and disease-free fish seeds and juveniles. Intense fish production compounds chronic stress through environmental factors that affect physiological homeostasis, growth performance, and immune systems thus producing fish that are more susceptible to diseases. Although antibiotics reduce the occurrence of diseases, their indiscriminate use has led to increased antibiotic resistance. The autochthonous gut microbiota plays a very important role in the health and growth of its host (Vine et al. 2004) by providing a level of protection against pathogenic agents in the gastrointestinal (GI) tract and facilitating host digestive function through the production of exogenous digestive enzymes and vitamins (Ray et al. 2012). The microbial community of the gut can therefore be considered to be transient in nature, which permits 
extending the probiotic concept of using live microbial preparations in aquaculture.

Probiotics can be helpful in diminishing the occurrence of disease or decreasing the seriousness of outbreaks (Carnevali et al. 2006). Commercially accessible probiotics are often relatively ineffectual because many are from non-fish sources, which means they are not generally able to survive or remain viable at optimum concentrations in fish digestive tracts (Ghosh et al. 2007). Several species of bacteria such as Bacillus (Bandyopadhyay 2004, Bhatnagar et al. 2012, Bhatnagar and Raparia 2014, Bhatnagar and Lamba 2015, 2017), Lactobacillus (Balcazar et al. 2007), and Pseudomonas (Nayak and Mukherjee 2011) have been isolated from fish intestines and are incorporated in formulated diets to study their effects on growth, nutritional quality, and immunity. The isolation of a probiotic from the gastro-intestinal tract of a host is the best approach to select candidate species (O'Sullivan 2001). The selection of probiotics is usually based on in vitro antagonism or the adhesion, colonization and growth in intestinal mucus (Vine et al. 2004). Therefore, the approach employed in this study was to isolate intestinal bacteria with favorable properties and to include high numbers of these bacteria in the feed fed to immature animals of the same species.

L. calbasu, which is valued for its specific taste and fetches high market prices, is facing decreasing population sizes in India. The culture of this species has also been ignored because of a lack of proper fish feed, the risk of diseases, and the lack of knowledge about the gut microbial community of this species. Owing to the importance of this candidate species, the present study was undertaken to isolate and screen autochthonous bacterial strains as potential probiotics and to incorporate them in the diet to improve the growth performance and immunity of the fish. Following isolation and screening, identification and characterization was done with genotypic and phenotypic methods.

\section{Materials and methods}

\section{Selection, procurement, and acclimation of fish}

Fish (20.5-23.6 cm total length and 91-148 g weight) were procured from a local fish farm, acclimated for 10 days, sampled, and gut homogenate was analyzed for intestinal microbial flora on Tryptone soya agar (TSA) plates $\left(37^{\circ} \mathrm{C}\right.$ for $\left.48 \mathrm{~h}\right)$ after serial dilution. The intestinal microfloral population (IMP) was determined and morphologically different colonies were picked up followed by restreaking to obtain pure strains. Bacterial suspension was also spread on starch agar media, carboxy methyl cellulase media, tributyrin agar media, and peptone gelatin agar to enumerate the amylase, cellulase, lipase, and peptidase producing ability of the gut microflora.

\section{Well Diffusion Assay and Probiotic Properties}

Nine morphologically different isolated strains from the gastrointestinal tract of $L$. calbasu were assessed in vitro for their inhibitory activity against the common fish pathogen Aeromonas by well diffusion assay (Lyon and Glatz 1993). Antagonistic activity was indicated by the appearance of clear inhibitory zone "halos" around the wells. The strains showing inhibitory zones above $20 \mathrm{~mm}$ were further evaluated for other probiotic properties. Acid tolerance was evaluated using the methods of Conway et al. (1987) and Pennacchia et al. (2004). The Gilliland et al. (1984) method was used to determine bile salt tolerance. Adhesion properties were evaluated by hydrophobicity assay (Savage 1992), aggregation assay (Del Re et al. 2000, Kos et al. 2003) and coaggregation assay (Handley et al. 1987). Adhesion properties were calculated with the following equations:

$$
\begin{gathered}
\text { Hydrophobicity }(\%)=\left[\left(O D_{450} \text { before }-O D_{450}\right.\right. \\
\text { after } \left.) / O D_{450} \text { before }\right] \times 100 \\
\text { Autoaggregation }(\%)=1-\left(A_{t} / A_{0}\right) \times 100
\end{gathered}
$$


Coaggregation $=\left(A_{x}+A_{y}\right) / 2-A(x+y) / A_{x}+A_{y} / 2 \times 100$

Where, $A_{t}$ is the absorbance at time $t=1,2,3,4$, or $5 \mathrm{~h} ; \mathrm{A}_{0}$ the absorbance at $\mathrm{t}=0 \mathrm{~h}$;

$\mathrm{Ax}$ and Ay are the absorbance of each of the two strains in the control tubes; and $(x+y)$ their mixture.

\section{Identification of probiotic bacterial strains}

The morphological identification of the bacterial strains with probiotic properties were carried out according to Bergey's Manual of Determinative Bacteriology (Holt et al. 1994) based on biochemical methods including Gram staining, motility, catalase test, growth range study, sugar utilization, starch hydrolysis, methyl red, the Vogus Prokauer test, and urea hydrolysis.

The molecular characterization of isolated strains showing antagonistic properties was done by isolating $16 \mathrm{~S}$ rDNA. DNA was isolated from the culture of isolated strains (Zhu et al. 1993). Quality was evaluated on $0.8-1.2 \%$ Agarose Gel, on which a single band of high-molecular weight DNA was observed. Isolated DNA was amplified with $16 \mathrm{~S}$ rRNA Specific Primer (8F and 1492R) using Veriti ${ }^{\circledR}$ 99 well Thermal Cycler (Model No. 9902). A single discrete PCR amplicon band of $1500 \mathrm{bp}$ was observed. The PCR amplicon was purified enzymatically and further subjected to Sanger Sequencing. The bi-directional DNA sequencing reaction of the PCR amplicon was carried out with 704F and 907R primers using a BDT v3.1 Cycle sequencing kit on an ABI 3730xl Genetic Analyzer. A consensus sequence of $16 \mathrm{~S}$ rDNA was generated from forward and reverse sequence data using aligner software. The 16S rDNA sequence was used to carry out the BLAST alignment search tool of the NCBI GenBank database. The first fifteen sequences were selected based on the maximum identity score and aligned using the multiple alignment software program Clustal W. A distance matrix was generated using the RDP database and a phylogenetic tree was constructed using MEGA5.

\section{Feeding trial}

Four experimental feeds (Diet C, Diet 1, Diet 2, and Diet 3) containing probiotic bacterial strains isolated from the gut of L. calbasu, A. aneurinilyticus, and Stenotrophomonas sp. were used in the study. Duckweed served as the primary plant protein source (Bhatnagar and Dhillon 2017). Pelleted feed was produced with a mechanical extruder from homogenous dough prepared by thoroughly grinding, sieving, and mixing the ingredients (groundnut oil cake, duckweed, wheat flour, rice bran, mineral mixture, chromic oxide). Probiotic bacterial strains were sprayed on the dried feed at a dose of $2000 \mathrm{CFU} \mathrm{g}^{-1}$ and were stored in air tight containers in a refrigerator at $4^{\circ} \mathrm{C}$. Then the feeding trial was conducted. Feed without probiotic served as control Diet C. The ingredient composition and the average proximate analysis of the formulated diets are presented in Table 1. Experimental fingerlings were procured from the Fish Seed Production Centre, Pawarkhera, Hoshangabad (Madhya Pradesh) and kept in glass aquaria $(60 \times 30 \times 30 \mathrm{~cm})$. The water in the aquaria was analysed fortnightly (American Public Health Association 1998), and it was partially renewed daily with previously equilibrated water maintained at a specific temperature $\left(26.11 \pm 0.03^{\circ} \mathrm{C}\right), \quad \mathrm{pH}$ (7.78 \pm 0.01$)$, dissolved oxygen $\left(7.27 \pm 0.04 \mathrm{mg} \mathrm{L}^{-1}\right)$, and low ammonia excretion $\left(349.31 \pm 4.13 \mathrm{mg} \mathrm{kg}^{-1}\right.$ $\mathrm{BW} \mathrm{d}^{-1}$ ). Pelleted feed were fed to fish fingerlings daily at $4 \%$ body weight in two portions (morning and evening) for 60 days. Fish from each treatment were bulk weighed fortnightly to adjust the feeding rates and to calculate the feed conversion ratio (FCR). Growth parameters were estimated following standard procedures (Garg et al. 2002).

\section{Determining immune response with phagocytic assay}

The phagocytic assay was performed according to the method by Siwicki et al. (1994) and Park and Jeong (1996). The phagocytic ratio (PR) and phagocytic index (PI) were determined by enumerating 100 
Table 1

Ingredients and proximate composition (\% dry weight) of the different diets

\begin{tabular}{|c|c|c|c|c|}
\hline Diets & Diet C & Diet 1 & Diet 2 & Diet 3 \\
\hline \multicolumn{5}{|l|}{ Ingredient composition } \\
\hline Ground nut oil cake & 650 & 650 & 650 & 650 \\
\hline Rice bran & 32 & 32 & 32 & 32 \\
\hline Wheat flour & 32 & 32 & 32 & 32 \\
\hline Duckweed & 266 & 266 & 266 & 266 \\
\hline A. aneurinilyticus (CFU gm $\left.{ }^{-1}\right)$ & 0 & 2000 & 0 & 1000 \\
\hline Stenotrophomonas (CFU gm $\left.{ }^{-1}\right)$ & 0 & 0 & 2000 & 1000 \\
\hline Mineral mixture* & 10 & 10 & 10 & 10 \\
\hline Chromic oxide $\left(\mathrm{Cr}_{2} \mathrm{O}_{3}\right)$ & 10 & 10 & 10 & 10 \\
\hline \multicolumn{5}{|l|}{ Proximate composition } \\
\hline Moisture (\%) & $2.94 \pm 0.035$ & $3.03 \pm 0.118$ & $3.06 \pm 0.140$ & $2.83 \pm 0.079$ \\
\hline Crude Protein (\%) & $40.82 \pm 0.365$ & $40.65 \pm 0.559$ & $39.42 \pm 0.238$ & $40.15 \pm 0.419$ \\
\hline Crude Fat (\%) & $9.13 \pm 0.043$ & $9.11 \pm 0.050$ & $9.21 \pm 0.094$ & $9.12 \pm 0.047$ \\
\hline Crude Fiber (\%) & $6.40 \pm 0.032^{b}$ & $6.80 \pm 0.109^{\mathrm{a}}$ & $6.51 \pm 0.021^{\mathrm{b}}$ & $6.49 \pm 0.113^{b}$ \\
\hline Total Ash (\%) & $7.50 \pm 0.187^{\mathrm{ab}}$ & $7.46 \pm 0.038^{\mathrm{ab}}$ & $7.57 \pm 0.075^{\mathrm{a}}$ & $7.19 \pm 0.023^{b}$ \\
\hline Nitrogen free extract (\%) & $33.52 \pm 0.400$ & $33.95 \pm 0.477$ & $34.22 \pm 0.497$ & $34.22 \pm 0.500$ \\
\hline Gross energy ( $\left.\mathrm{kJ} \mathrm{g}^{-1}\right)$ & $19.01 \pm 0.018^{\mathrm{a}}$ & $19.03 \pm 0.024^{\mathrm{a}}$ & $18.83 \pm 0.021^{b}$ & $18.96 \pm 0.030^{\mathrm{a}}$ \\
\hline Feed Phosphorus (\%) & $1.40 \pm 0.019$ & $1.44 \pm 0.019$ & $1.47 \pm 0.038$ & $1.39 \pm 0.017$ \\
\hline
\end{tabular}

* Nutritional value per kg: copper 312 mg, cobalt 35 mg, magnesium 2.114 g, iron 979 mg, zinc 2 mg, iodine 15 mg, L-methionine $1.920 \mathrm{~g}$, L-lysine monohydrochloride $4.4 \mathrm{~g}$, calcium 30\%, phosphorous $8.25 \%$. Means in the same row with different superscripts letters are significantly $(\mathrm{P}<0.05)$ different (Duncan's multiple range test). All values are presented as means $\pm \mathrm{SE}$.

phagocytes per slide under a microscope, and then calculating the average of three slides.

\section{Challenge trial}

After feeding for 60 days, 10 fish from each treatment were challenged with the pathogenic strain $A$. hydrophila (MTCC 1739) that was cultured and maintained in the selective medium. The fish in all replicates were immersed in a suspension of $A$. hydrophila approximately $10^{5} \mathrm{CFU} \mathrm{ml}^{-1}$ followed by a second immersion in approximately $10^{7} \mathrm{CFU} \mathrm{ml}^{-1}$ after 7 days. Mortality percentages were measured for 10 days, and observations indicated that mortality plateaued after one week (Sahoo et al. 1998) and the relative percentage survival (RPS) was calculated with the following formula (Ellis 1988):

\section{RPS $=1$ - (Percent mortality in treated group) Percent mortality in control group) $\times 100$}

A Kaplan-Meier survivorship curve was prepared on MS Excel to show the trend during the challenge trial with $A$. hydrophila for 10 days (Berwick et al. 2004).

\section{Statistical analysis}

Significant differences among treatment groups were tested with analysis of variance (ANOVA) followed by Duncan's multiple range tests (Duncan 1955) for the experiments. Statistical significance was designated at a probability value of $\mathrm{P}<0.05$. All statistics were performed using SPSS Version 18.0.

\section{Results}

\section{Isolation of microorganisms from the $L$. calbasu digestive tract}

The mean population of total intestinal microflora (TIM) on TSA plates was found to be $2.12 \times 10^{5} \mathrm{CFU}$ $\mathrm{g}^{-1}$ (Fig. 1). Nine morphologically different colonies 


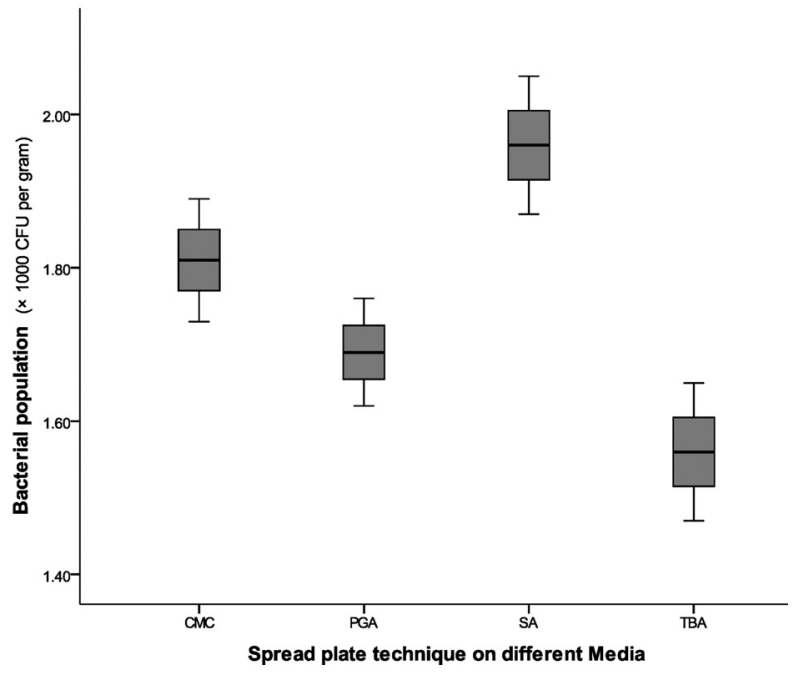

Figure 1. Cellulolytic, proteolytic, amylolytic, and lipolytic bacterial population $\left(\times 10^{3} \mathrm{CFU} \mathrm{g}^{-1}\right)$ isolated with the Spread plate technique on different media.

(LC1-LC9) were picked up from the plates; then the streak plate method was applied to ensure purity. Distinctly amylolytic, cellulolytic, lipolytic, and proteolytic microflora were also identified from the culture plates using selective media (Fig. 1).

\section{Well diffusion assay and probiotic properties}

Four strains, LC1, LC4, LC7, and LC9, produced clear inhibitory zones against the pathogenic strain with diameters exceeding $20 \mathrm{~mm}$ (Table 2 and Fig. 2A). The strains LC1, LC4, LC7, and LC9 also showed acid $(\mathrm{pH} 2.5)$ and bile (0.3\%) tolerance indicating their tolerance to acidic and basic environments inside the fish gut. Positive adhesion properties were exhibited by all four strains (Table 3). Cell surface hydrophobicity was evaluated according to the ability of the microorganisms to partition into hydrocarbon from phosphate buffered solution (PBS). The results of using xylene and toluene to evaluate the hydrophobic cell surface properties of strains LC1, LC4, LC7, and LC9 were positive. The autoaggregation rate of strains $\mathrm{LC} 1, \mathrm{LC} 4, \mathrm{LC} 7$, and LC9 were determined during a period of $5 \mathrm{~h}$. Coaggregations of the isolates with A. hydrophila were expressed as the percentage reduction in the absorbance of a mixed suspension after $5 \mathrm{~h}$.

\section{Morphological and molecular identification}

Morphological identifications of bacterial strains that showed antagonistic activity were conducted with

Table 2

Inhibition zones of isolated bacteria strains against Aeromonas hydrophila

\begin{tabular}{lll}
\hline \hline & \multicolumn{2}{l}{ Inhibition zone $(\mathrm{mm})$} \\
\cline { 2 - 3 } Isolated strains & Mean value & Range \\
\hline \hline LC1 & $20.62 \pm 0.68$ & $18-24$ \\
LC2 & $06.62 \pm 0.39$ & $5-8$ \\
LC3 & $06.87 \pm 0.59$ & $5-9$ \\
LC4 & $20.00 \pm 0.53$ & $18-22$ \\
LC5 & $06.75 \pm 0.42$ & $5-8$ \\
LC6 & $07.00 \pm 0.25$ & $6-8$ \\
LC7 & $20.25 \pm 0.63$ & $18-23$ \\
LC8 & $06.62 \pm 0.39$ & $5-8$ \\
LC9 & $21.37 \pm 0.58$ & $19-24$ \\
\hline \hline
\end{tabular}

Table 3

Adhesion properties of different strains (inhibition zones greater than $20 \mathrm{~mm}$ ) with different testing methods: hydrophobicity, autoaggregation, and coaggregation

\begin{tabular}{|c|c|c|c|c|c|c|c|c|}
\hline \multirow[b]{3}{*}{ Strains } & & & \multicolumn{6}{|l|}{ Aggregation } \\
\hline & \multicolumn{2}{|c|}{ Hydrophobicity } & \multicolumn{5}{|l|}{ Auto- (h) } & \multirow[b]{2}{*}{ Co- } \\
\hline & Xylene & Toluene & 1 & 2 & 3 & 4 & 5 & \\
\hline LC1 & $46.09 \pm 0.09$ & $24.97 \pm 0.12$ & $54.16 \pm 3.40$ & $70.83 \pm 3.40$ & $108.33 \pm 9.00$ & $162.5 \pm 5.89$ & $316.66 \pm 6.80$ & $3.16 \pm 0.06$ \\
\hline LC4 & $64.19 \pm 0.18$ & $43.12 \pm 0.20$ & $33.33 \pm 7.85$ & $349.99 \pm 28.32$ & $422.22 \pm 9.07$ & $455.55 \pm 9.07$ & $544.44 \pm 9.07$ & $6.68 \pm 0.11$ \\
\hline LC7 & $31.25 \pm 0.37$ & $7.17 \pm 0.16$ & $57.13 \pm 6.73$ & $352.37 \pm 33.22$ & $457.13 \pm 6.73$ & $538.09 \pm 7.77$ & $604.76 \pm 19.44$ & $5.13 \pm 0.05$ \\
\hline LC9 & $6.71 \pm 0.07$ & $22.82 \pm 0.14$ & $70.83 \pm 3.40$ & $350.00 \pm 11.78$ & $450.00 \pm 11.78$ & $537.5 \pm 5.89$ & $641.66 \pm 6.80$ & $3.28 \pm 0.05$ \\
\hline
\end{tabular}

All values are means \pm SE. 

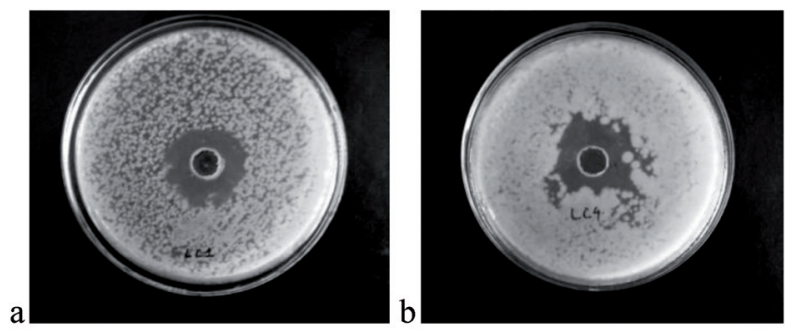

A

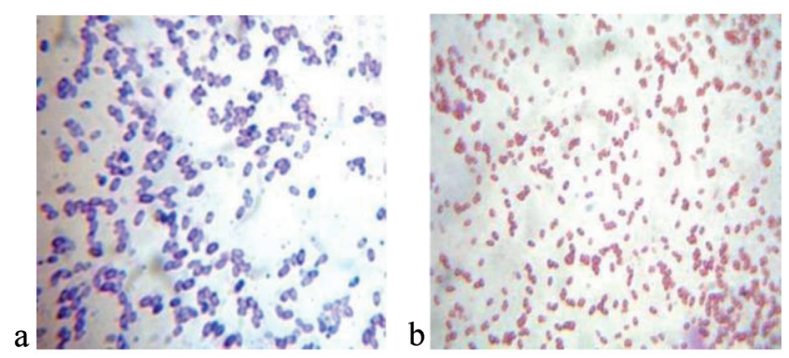

B

Figure 2. A. Antimicrobial activity of bacterial strains isolated with the Well diffusion assay: Inhibition zones of probiotic strains (a. LC1 and b. LC4) for pathogenic A. hydrophila. B. Rod shaped bacteria of strain a. LC1 (A. aneurinilyticus) exhibiting Gram positive reactions. Round bacteria of the strain b. LC4 (Stenotrophomonas sp.) showing Gram negative reactions. properties showed similarity with Aneurinibacillus aneurinilyticus, strain DSM 5562 (Accession Number: NR 112203.1) and Stenotrophomonas sp., BAB-5307 (Accession Number: KT 254643.1), respectively, based on nucleotide homology in the phylogenetic analysis referred to in the NCBI database (Fig. 3).

\section{Growth and immune response}

Growth performance was observed to be significantly $(\mathrm{P}<0.05)$ higher in the fingerlings fed diet 1 that incorporated the probiotic bacteria $A$. aneurinilyticus in comparison to the control without the probiotic. ANOVA and then Duncan's multiple range test revealed significantly $(\mathrm{P}<0.05)$ high fish growth in live weight gain (1.56 $\pm 0.018 \mathrm{~g})$, percentage of body weight gain (51.20 $\pm 0.677 \%)$, growth per day (\%) in BW $(0.68 \pm 0.07)$, and specific growth rate $(0.30 \pm$ 0.003). These results refer to the group of fingerlings that were fed diet 1 containing the probiotic $A$. biochemical methods. The growth of LC1, LC4, LC7, and LC9 was observed at a wide range of temperatures, $\mathrm{pH}$, and salinity percentages. Gram staining showed a positive reaction, while that of the other strains was negative (Fig. 2B). LC1, LC4, and LC9 exhibited motility. The catalse test for all strains was positive. LC1 and LC4 were positive for sugar utilization, while only LC1 exhibited starch hydrolysis. All strains responded negatively to methyl red, the Vogus Prokauer test, and urea hydrolysis. These results revealed that the LC1 strain belonged to the class Bacilli, while LC4 showed characteristics of the family Gammaproteobacteria.

The 16S rDNA based on the molecular characterization of the strains revealed the identification of LC1 and LC4, whereas LC7 and LC9 were found to be mixed cultures. The isolated strains of LC1 and LC4 with significant probiotic
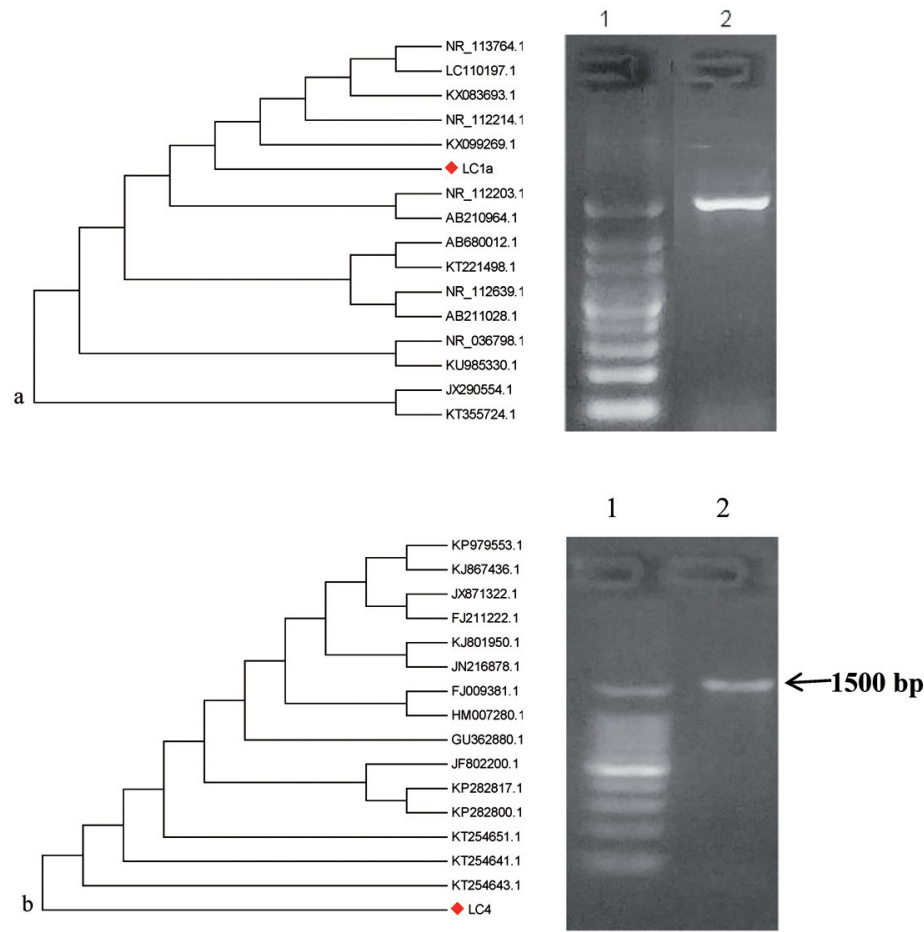

Figure 3. Dendogram showing phylogenetic relations of a. LC1 and b. LC4 with other closely-related strains retrieved from the NCBI GenBank and referenced to accession numbers. Horizontal bars in the dendogram $=$ branch length $1.2 \%$ Agarose gel showing single $1500 \mathrm{bp}$ of $16 \mathrm{~S}$ rDNA amplicon. Lane 1: 100bp DNA ladder; Lane 2: 16S rDNA amplicon (a. LC1, b. LC4). 
Table 4

Growth performance of Labeo calbasu fed on diets containing isolated probiotic bacterial strains (Diet C = Control, Diet $1=A$. aneurinilyticus, Diet 2 = Stenotrophomonas sp., Diet $3=$ A. aneurinilyticus + Stenotrophomonas sp.)

\begin{tabular}{lllll}
\hline \hline Growth parameters & Diet C & Diet 1 & Diet 2 & Diet 3 \\
\hline \hline Initial weight (g) & $3.04 \pm 0.009$ & $3.05 \pm 0.014$ & $3.04 \pm 0.010$ & $3.05 \pm 0.009$ \\
Final weight (g) & $4.01 \pm 0.013^{\mathrm{d}}$ & $4.62 \pm 0.020^{\mathrm{a}}$ & $4.26 \pm 0.032^{\mathrm{c}}$ & $4.42 \pm 0.017^{\mathrm{b}}$ \\
Live weight gain (g) & $0.97 \pm 0.006^{\mathrm{d}}$ & $1.56 \pm 0.018^{\mathrm{a}}$ & $1.22 \pm 0.023^{\mathrm{c}}$ & $1.37 \pm 0.009^{\mathrm{b}}$ \\
Survival rate (\%) & 100 & 100 & 100 & 100 \\
Growth (\%) gain in BW & $31.94 \pm 0.147^{\mathrm{d}}$ & $51.20 \pm 0.677^{\mathrm{a}}$ & $40.13 \pm 0.648^{\mathrm{c}}$ & $44.76 \pm 0.176^{\mathrm{b}}$ \\
Growth/day (\%) in BW & $0.46 \pm 0.020^{\mathrm{d}}$ & $0.68 \pm 0.007^{\mathrm{a}}$ & $0.56 \pm 0.008^{\mathrm{c}}$ & $0.61 \pm 0.002^{\mathrm{b}}$ \\
Specific Growth Rate (SGR) (\% BW d ${ }^{-1}$ ) & $0.20 \pm 0.001^{\mathrm{d}}$ & $0.30 \pm 0.003^{\mathrm{a}}$ & $0.24 \pm 0.004^{\mathrm{c}}$ & $0.27 \pm 0.001^{\mathrm{b}}$ \\
Feed Conversion Ratio (FCR) & $3.25 \pm 0.014^{\mathrm{a}}$ & $2.21 \pm 0.038^{\mathrm{d}}$ & $2.67 \pm 0.032^{\mathrm{b}}$ & $2.47 \pm 0.006^{\mathrm{c}}$ \\
Gross Conversion Ratio (GCE) & $0.31 \pm 0.001^{\mathrm{d}}$ & $0.45 \pm 0.008^{\mathrm{a}}$ & $0.48 \pm 0.004^{\mathrm{c}}$ & $0.40 \pm 0.001^{\mathrm{b}}$ \\
Protein Efficiency Ratio (PER) & $0.80 \pm 0.004^{\mathrm{d}}$ & $1.28 \pm 0.017^{\mathrm{a}}$ & $1.00 \pm 0.016^{\mathrm{c}}$ & $1.12 \pm 0.004^{\mathrm{b}}$ \\
\hline \hline
\end{tabular}

Means in the same row with different superscripts letters are significantly $(\mathrm{P}<0.05)$ different (Duncan's multiple range test). All values are presented as means $\pm \mathrm{SE}$.

aneurinilyticus at a dose of $2000 \mathrm{CFU} \mathrm{g}^{-1}$ of feed in comparison to the other dietary treatments. A significantly $(\mathrm{P}<0.05)$ lower FCR $(2.21 \pm 0.038)$ was observed in the group fed diet 1 ; this clearly illustrated the best utilization of the available feed. The FCR was high in the control group (3.25 \pm $0.014)$, and significantly $(\mathrm{P}<0.05)$ high values of digestibility parameters viz., gross conversion efficiency (GCE) $(0.45 \pm$ 0.008 ) and protein efficiency ratio (PER)

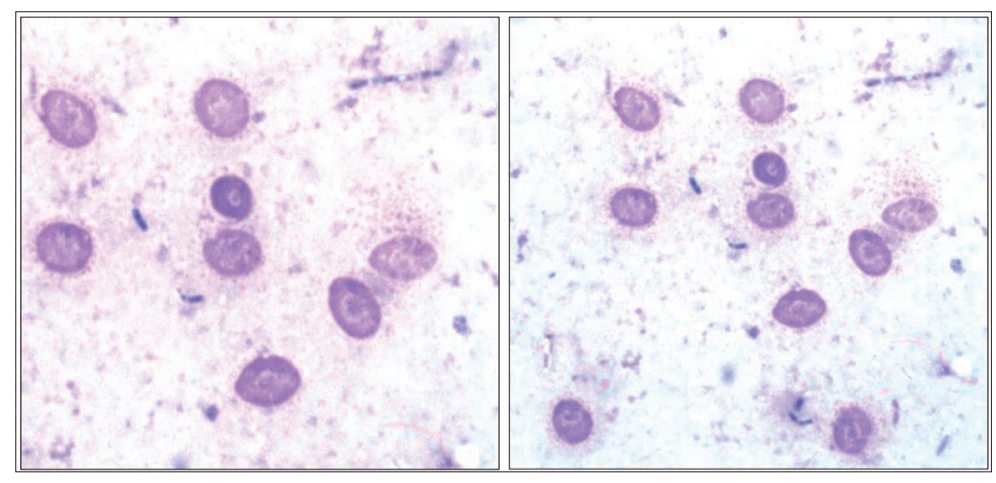

Figure 4. Phagocytic cells observed in the blood of L. calbasu fed different diets supplemented with probiotics after 60 day feeding trials (1000X).
$(1.28 \pm 0.017)$, were observed in the group of fish fed the diet supplemented with $A$. aneurinilyticus. Significantly low ammonia excretion and phosphate production was observed in the group fed diet 1 containing $A$. aneurinilyticus. Initial ammonia excretion was at a high level $8 \mathrm{~h}$ after feeding, and there was a second peak $18 \mathrm{~h}$ after feeding, while peak values of reactive phosphate production occurred $8 \mathrm{~h}$ after feeding the fingerlings with a second peak $14 \mathrm{~h}$ after feeding (data not shown) (Table 4).

Phagocytic cells were observed in the blood of fish groups fed probiotic bacterial strains when incubated with the pathogen A. hydrophila (Fig. 4). The phagocytic ratios and indices in the fish fed with various selected probiotic strains were significantly $(\mathrm{P}<$ 0.05) higher than those in the control fish during the assay period. Maximum values of the phagocytic ratio and phagocytic index were observed in dietary treatment 1 (containing A. aneurinilyticus at 2000 $\mathrm{CFU} \mathrm{g}^{-1}$ feed) than in the fish fed the control diet for 60 days (Fig. 5). Fish fed probiotic-based diets showed enhanced non-specific immune response activities and resistance to experimental challenges with pathogenic bacteria.

\section{Challenge trial}

After 60 days of the feeding trial, a challenge trial was conducted with pathogenic $A$. hydrophila for 10 days to calculate mortality and relative survival percentages. The lowest, statistically significant $(\mathrm{P}<0.05)$ mortality $(6.67 \pm 3.33 \%)$ was observed in diet 1 with the probiotic bacterial strain $A$. aneurinilyticus, which also porduced the highest relative survival 

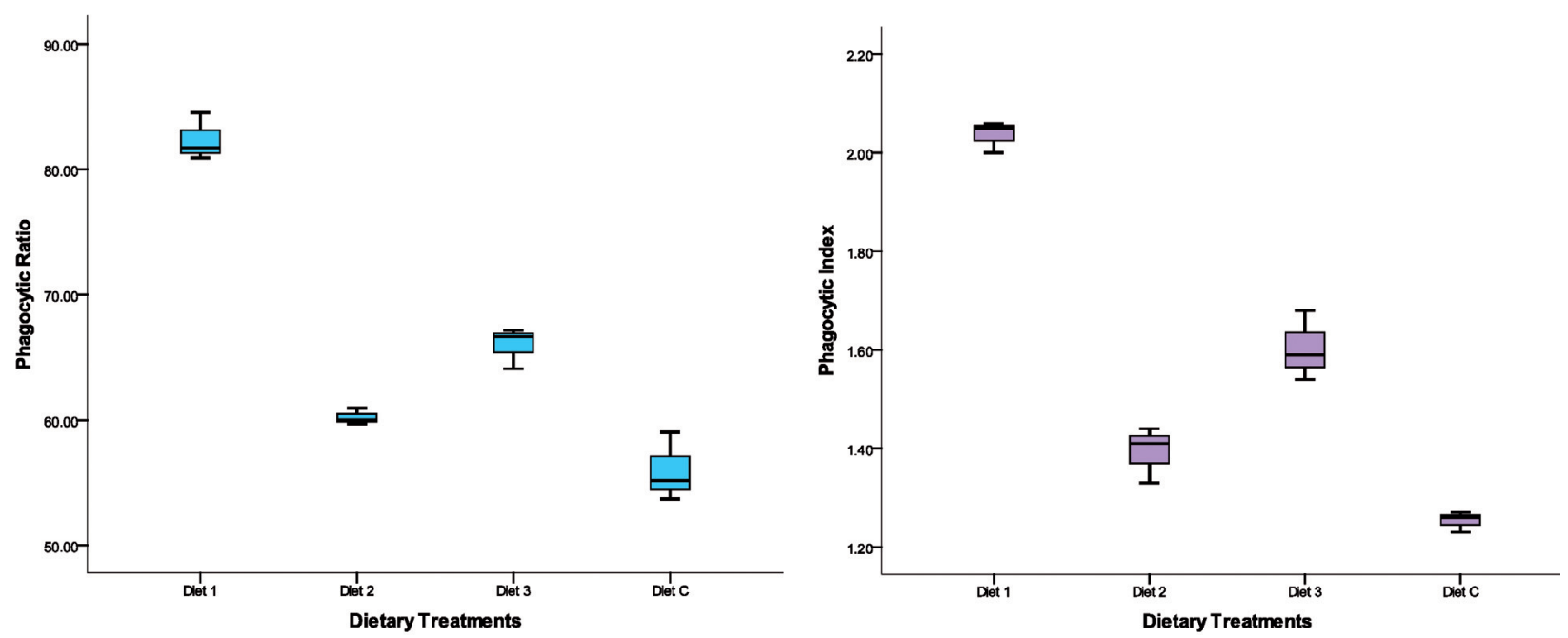

Figure 5. Box plots depicting phagocytic ratio (\%) and phagocytic index of L. calbasu (means \pm SE of mean) in different dietary treatments containing isolated probiotic bacterial strain (Diet $\mathrm{C}=$ Control, Diet $1=A$. aneurinilyticus, Diet $2=$ Stenotrophomonas sp., Diet $3=A$. aneurinilyticus + Stenotrophomonas sp.).

percentage $(87.78 \pm 6.18 \%)$ after 10 days of the challenge trial. The Kaplan-Meier survival plots and the survivorship curve of the fish after the challenge trial with $A$. hydrophila are presented in Fig. 6.

\section{Discussion}

Microbial colonization, establishment, composition, and diversity in fish GI tracts is a complex process that is believed to be a reflection of the microbial composition of the rearing water, diet, and environment (Nayak 2010). The results of the present investigation indicated that a considerable bacterial population was found in the L. calbasu intestinal tract. These studies further indicated that the gut bacterial population of this species exhibited amylolytic, proteolytic, cellulolytic, and lipolytic properties that suggested considerable protein digestibility. The enzyme producing ability of the microbial flora isolated by Rani et al. (2004) supports the results of the present research. Bairagi et al. (2002) also report

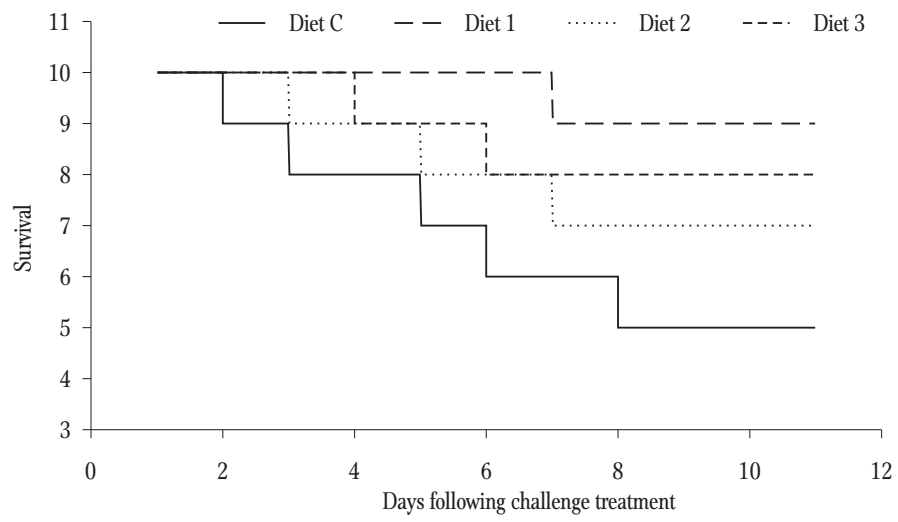

(A)

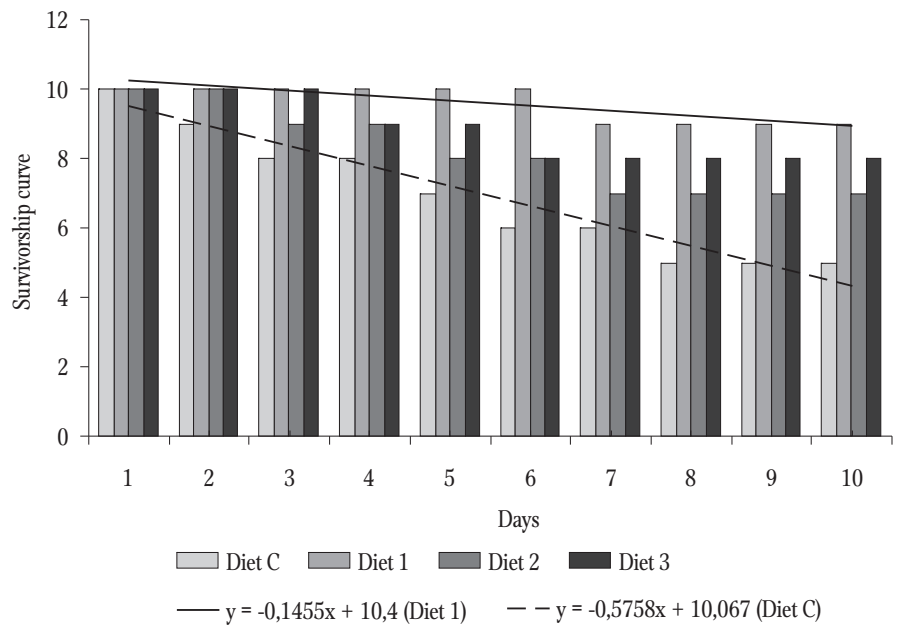

(B)

Figure 6. A. Plots of Kaplan-Meier survival estimates of fish after the challenge trial in different treatments; B. Survivorship curve of L. calbasu fed on diets containing different probiotic strains in a challenge trial with $A$. hydrophila for 10 days (Diet C = Control, Diet $1=$ A. aneurinilyticus, Diet $2=$ Stenotrophomonas sp., Diet $3=$ A. aneurinilyticus + Stenotrophomonas sp.). 
high proteolytic enzyme activity in herbivorous and carnivorous fish.

The isolated strain exhibited antibacterial activities against the pathogen $A$. hydrophila and grew in a wider range of temperatures, $\mathrm{pH}$, and salt concentrations. Similar properties were exhibited by the gastrointestinal bacteria isolated from all the three species of Indian major carps viz., Labeo rohita (Hamilton), Gibelion catla (Hamilton), and Cirrhinus mrigala (Hamilton), in a potential probiotic that Nayak and Mukherjee (2011) screened. In the present investigation, characterizing the isolated microorganisms revealed that they could grow within wide ranges of temperature $\left(15-55^{\circ} \mathrm{C}\right)$ and $\mathrm{pH}$ (5-11). This could have been because the fish are poikilotherms, i.e., their body temperature depends on environmental temperatures. This probably enabled the organisms to adapt to a wide range of temperatures and $\mathrm{pH}$ (Ghosh et al. 2002). The hydrophobicity (\%) of the A. aneurinilyticus and Stenotrophomonas sp. strains revealed their ability to colonize the gut surface in L. calbasu. Kos et al. (2003), Bhatnagar et al. (2012), Bhatnagar and Raparia (2014), and Bhatnagar and Lamba (2015, 2017) report similar results. Bacterial adhesion is based on non-specific physical interactions between two surfaces that enable specific interactions between adhesins and complementary receptors (Rojas and Conway 1996). Probiotic strain autoaggregation appeared to be requisite for adhesion to intestinal epithelial cells, and coaggregation abilities could form a barrier that intercepts colonization by pathogenic microorganisms. The autoaggregation and co-aggregation abilities exhibited by the strains isolated could have initiated a strong host protective mechanism against gastrointestinal tract infection (Sansawat and Thirabunyanon 2009).

The strains isolated were acid and bile tolerant, which is an important criterion for potential probiotic strains that ensures their survival and growth in the fish GI tract and that they are beneficial to the fish (Balcazar et al. 2007). Nandi et al. (2017) isolated potential probiotic autochthonous bacterial strains from the gut of freshwater teleosts, including $L$. calbasu, and this supports the results of the present study. A. aneurinilyticus showed growth at a high temperature and salinity, and Das et al. (2016) report similar results in a species of Aneurinibacillus isolated from soil that exhibited mosquitocidal potential.

The predominance of Gram negative (71-75\%) and less of Gram positive (24-28\%) rods in the intestines of L. calbasu was observed in morphological and physiological groupings of microflora. Similar results were observed for L. rohita (Hossain et al. 1999), C. catla (Bhatnagar et al. 2012), and C. mrigala (Bhatnagar and Lamba 2015). In the present study, the physical and the biochemical characters of potential probiotic bacterial isolates were identified as A. aneurinilyticus and Stenotrophomonas as in Holt et al. (1994). The prokaryotic rDNA genes contained highly conserved sequences which were complementary to the Shine-Dalgarno (SD) sequence. The potential utility of conserved regions to identify or amplify the rDNA gene followed by the exploitation of more variable regions of the gene spacers to detect or identify bacteria is currently in practice (Barry et al. 1990). A similar method was employed in the present study when identifying the cultures in LC1 and LC4, which were found to have similarities with A. aneurinilyticus and Stenotrophomonas, respectively.

However, to the best of the authors' knowledge $A$. aneurinilyticus and Stenotrophomonas have not been reported previously in the GI tracts of any fish species. The use of Aneurinibacillus sp. DB4 (strain NCIMB 13288) has been reported as a single cell protein in fish and shellfish, and Stenotrophomonas sp. isolated by Salvadori et al. (2006) that exhibited the capability of degrading low-ethoxylated nonylphenol polyethoxylate mixtures supports the use of isolated strains as probiotics. A. aneurinilyticus, which decomposed thiamine and assimilated carbohydrates, and the nitrate reduction and strong lipolytic activity that Stenotrophomonas (Bergey's Manual of Systematics of Archaea and Bacteria 2015) exhibited are properties required for potential probiotics. The results of the present study revealed that autochthonous bacteria existed in the intestine of the fish species studied, which is imperative for screening probiotics for better 
colonization in the gut to provide immunity and to enhance the growth of candidate species. The results of the present research concur with the outcome of various studies that used different bacterial strains as probiotics in various fish species (Nayak 2010, Bhatnagar et al. 2012, Mohapatra et al. 2012, Giri et al. 2013, Bhatnagar and Lamba 2017). The fish from the diet 1 group containing $A$. aneurinilyticus showed the highest growth performance and immune response. This could have been because $A$. aneurinilyticus belongs to the class Bacilli, is a Gram positive aerobic rod-shaped bacterium that forms endospores, and is resistant to chemical and physical agents (Bergey's Manual of Determinative Bacteriology). Congruent outcomes were observed when supplementing with B. cereus (Bhatnagar and Lamba 2017) and B. coagulans (Bhatnagar et al. 2012, Bhatnagar and Raparia 2014) in C. mrigala and $C$. catla, respectively, which improved growth performance in live weight gain, increased percentages of body weight gain, growth per day, specific growth rate (SGR), and immune response. Fish farmers are not interested in culturing this species because of its slow growth rate. The results of the present study will be beneficial in enhancing the culture of this species using probiotic supplementation in intense production. Most of the immunostimulants used in aquaculture are believed to enhance innate immunity in fish by stimulating leukocyte activity. Leukocytes derive their bactericidal power from a vast range of cellular functions, including phagocytosis. Increases in the phagocytic ratio with increases in growth performance clearly revealed the immunostimulatory effect of the probiotic strains used.

The mortality percentages during the challenge trial with $A$. hydrophila were low in the groups fed the probiotic bacterial strains, and the highest was noted in the group fed feed supplemented with $A$. aneurinilyticus. The survivorship plot indicated that there was a significant difference between the survivorship curves in each treatment, and Bhatnagar and Lamba (2017) report a similar plot. The Kaplan-Meier survival plots indicated that mortality was observed initially after the challenge trial in all groups; however, thereafter, the survival of the groups fed the probiotic were high, while the number of fingerlings declined in those fed the control diets without probiotic supplementation. This demonstrated the immunomodulatory effects of the diets supplemented with probiotics. The survivorship curve showed the same with a slope of lesser value for diet 1 than for control $C$ in which the fish were not fed probiotics. The probiotics can confer pathogen resistance through competitive exclusion and by producing various metabolites that culminate in elevated immunological responses and improved fish survival (Balcazar et al. 2006). Furthermore, knowledge about the gut microbial community of $L$. calbasu provides useful information on how to monitor and manage populations of this species better in natural waters and in aquaculture.

\section{Conclusion}

The autochthonous bacterial strains that exhibited potential probiotic properties when incorporated in the diet of $L$. calbasu resulted in high growth performance and increased immunological response against pathogens. In order for the applicable probiotics to be significant in practice, they must be applicable in large-scale aquaculture and will have to be formulated and produced under industrial conditions to control quality and prevent contamination risks. Obviously, much effort will have to be invested in the production of such multispecies and in the methods needed to preserve them and to validate their quality.

Acknowledgments. O. Dhillon is thankful to UGC, New Delhi India for a Maulana Azad Research Fellowship.

Authors contribution. A.B. designed the experiment, procured the experimental fish, supervised the research work, and checked the manuscript. OD executed the experiment and analyzed the sample and statistical data. Both authors participated in writing the manuscript.

\section{ORCID}

Anita Bhatnagar. (D) http://orcids.org/0000-0002-0159-4096 


\section{References}

American Public Health Association 1998 - Standard methods for the examination of water and waste water $-20^{\text {th }}$ edn. American Public Health Association, New York.

Bairagi A., Sarkarghosh K., Sen S.K., Ray A.K. 2002 - Duckweed (Lemna polyrrhiza) leaf meal as source of feedstuff in formulated diets for rohu (Labeo rohita) fingerlings after formulation with a fish intestinal bacterium Bioresour. Technol. 85: 17-23.

Balcazar J.L., de Blas I., Ruiz-Zarzuela I., Cunningham D., Vendrell D., Muzquiz J.L. 2006 - The role of probiotics in aquaculture - Vet. Microbiol. 114: 173-186.

Balcazar J.L., Blas D., Zarzuela I.R., Vendrell D., Girones O., Muzquiz J.L. 2007a - Sequencing of variable regions of the $16 \mathrm{~S}$ rRNA gene for identification of lactic acid bacteria isolated from the intestinal microbiota of healthy salmonids - Comp. Immunol. Microbiol. Infect. Dis. 30: 111-118.

Balcazar J.L., de Blas I., Ruiz-Zarzuela I., Vendrell D., Girones O., Muzquiz J.L. 2007b - Enhancement of the immune response and protection induced by probiotic lactic acid bacteria against furunculosis in rainbow trout (Oncorhynchus mykiss) - FEMS Immunol. Med. Mic. 51: 185-193.

Bandyopadhyay P. 2004 - Improvement of growth, nutritional quality and immunity of Indian major carps through probiotic supplement - Ph.D. thesis, Vidyasagar University, Midnapore-721102, West Bengal. India.

Barry T., Powell R., Gannon F.A. 1990 - A general method for the development of DNA probes for microorganisms Nat. Biotechnol. 8: 233-236

Bergey's Manual of Systematics of Archaea and Bacteria 2015 - Bergey's Manual Trust - John Wiley and Sons.

Berwick V., Cheek L., Ball J. 2004 - Statistics review 12: Survival analysis - Crit. Care 8: 389-394.

Bhatnagar A., Dhillon O. 2017 - Evaluation of optimum protein requirement and cost effective eco-friendly source for Labeo calbasu (Hamilton, 1822) - J. Fish. Aquat. Sci. 12: 273-283.

Bhatnagar A., Lamba R. 2015 - Antimicrobial ability and growth promoting effects of feed supplemented with probiotic bacterium isolated from gut microflora of Cirrhinus mrigala - J. Integr. Agric. 14: 583-592.

Bhatnagar A., Lamba R. 2017 - Molecular characterization and dosage application of autochthonous potential probiotic bacteria in Cirrhinus mrigala - J Fisheries Sci.com 11(2): 46-56.

Bhatnagar A., Raparia S. 2014 - Optimum dietary inclusion level of Bacillus coagulans for growth and digestibility improvement for Catla catla (Hamilton) - Int. J. Curr. Res. Rev. 6(7): 1-10.
Bhatnagar A., Raparia S., Kumari S. 2012 - Isolation and Influence of Bacillus coagulans CC1 on growth performance and digestive enzyme activities of Catla catla - J. Nat. Sci. Sustainable Technol. 6: 237-253

Carnevali O., de Vivo L., Sulpizio R., Gioacchini G., Olivotto I., Silvi S., Cresci A. 2006 - Growth improvement by probiotic in European sea brass juveniles (Dicentrachus labrax, L.), with particular attention to IGF-1, myostatin and cortiosol gene expression - Aquaculture 258: 430-438

Conway P.L., Gorbach S.L., Goldin B.R. 1987 - Survival of lactic acid bacteria in the human stomach and adhesion to intestinal cells - J. Dairy Sci. 70: 1-12.

Das D., Chatterjee S.N., Dangar T.K. 2016 - Characterization and mosquitocidal potential of the soil bacteria Aneurinibacillus aneurinilyticus isolated from Burdwan, West Bengal, India - Proc. Natl. Acad. Sci. India Sect. B Biol. Sci. 86: 707-713.

Del Re B., Sgorbati D., Miglioli M., Palenzona D. 2000 Adhesion, autoaggregation and hydrophobicity of 13 strains of Bifidobacterium longum - Lett. Appl. Microbiol. 31: 438-442.

Duncan D.B. 1955 - Multiple range and Multiple F Tests Biometrics 11: 1-42.

Ellis A.E. 1988 - Fish Vaccination - Academic Press, London, $84 \mathrm{p}$.

Garg S.K., Bhatnagar A., Kalla A., Johal M.S. 2002 - Experimental Ichthyology - CBS Publications and Distributors, New Delhi.

Ghosh K., Sen S.K., Ray A.K. 2002 - Characterization of Bacilli isolated from gut of rohu, Labeo rohita, fingerlings and its significance in digestion - J. Appl. Aquacult. 12: 33- 42.

Ghosh S., Sinha A., Sahu C. 2007 - Isolation of putative probionts from the intestines of Indian major carps - Isr. J. Aquacult. - Bamidgeh 59: 127-132.

Gilliland S.E., Staley T.E., Bush L.J. 1984 - Importance of bile tolerance of Lactobacillus acidophilus used as a dietary adjunct - J. Dairy Sci. 67: 3045-3051.

Giri S.S., Sukumaran V., Oviya M. 2013 - Potential probiotic Lactobacillus plantarum VSG-3 improves the growth, immunity, and disease resistance of tropical freshwater fish, Labeo rohita - Fish Shellfish Immunol. 34: 660-666.

Handley P.S., Harty D.W.S., Wyatt J.E., Brown C.R., Doran J.P., Gibbs A.C.C. 1987 - A comparison of the adhesion, coaggregation and cell-surface hydrophobicity properties of fibrillar and fimbriate strains of Streptococcus salivarius - J Gen. Microbiol. 133: 3207-3217.

Holt G.J., Krieg N.R., Sneath P.H.A., Staley J.T., Williams S.T. 1994 - Bergey's manual of determinative bacteriology 9th edn. Philadelphia, PA: Lippincott Williams and Wilkins. 
Hossain M.M., Uddin M.N., Islam M.N., Chakraborty S.C., Kamal M. 1999 - Study on the intestinal bacteria of Labeo rohita (Ham.) - Bangladesh J. Fish. Res. 3: 63-66.

Kos B., Šušković J., Vuković S., Šimpraga M., Frece J., Matošić S. 2003 - Adhesion and aggregation ability of probiotic strain Lactobacillus acidophilus M92 - J. Appl. Microbiol. 94: 981-987

Lyon W.J., Glatz B.A. 1993 - Isolation and purification of propionicin PLG-1, a bacteriocin produced by a strain of Propiobacterium theonii - Appl. Environ. Microbiol. 59: 83-87.

Mohapatra S., Chakraborty T., Prusty A.K., Das P., Paniprasad K., Mohanta K.N. 2012 - Use of different microbial probiotics in the diet of rohu, Labeo rohita fingerlings: effects on growth, nutrient digestibility and retention, digestive enzyme activities and intestinal microflora - Aquac. Nutr. 18: 1-11.

Nandi A., Dan S.K., Banerjee G., Ghosh P., Ghosh K., Ringo O., Ray A.K. 2017 - Probiotic potential of autochthonous bacteria isolated from the gastrointestinal tract of four freshwater teleosts - Probiotics Antimicro Prot. 9: 12-21.

Nayak S.K. 2010 - Role of gastrointestinal microbiota in fish Aquacult. Res. 41: 1553-1726.

Nayak S.K., Mukherjee S.C. 2011 - Screening of gastrointestinal bacteria of Indian major carps - Aquacult. Res. 42: 1034-1041.

O’Sullivan D.J. 2001 - Screening of intestinal microflora for effective probiotic bacteria - J. Agric. Food Chem. 49: 1751-1760.

Park K.H., Jeong H.D. 1996 - Enhanced resistance against Edwardsiella tarda infection in tilapia (Oreochromis niloticus) by administration of protein-bound polysaccharide - Aquaculture 141: 135-143.

Pennacchia C., Ercolini D., Blaiotta G., Pepe O., Mauriello G., Villani F. 2004 - Selection of Lactobacillus strains from fermented sausages for their potential use as probiotics Meat Sci. 67: 309-317.
Rani S., Garg S.K., Sabhlok V.P., Bhatnagar A. 2004 - Intestinal enzyme activity and enzyme producing microbial flora in relation to feeding behavior in some brackish water teleosts - J. Aquacult. 12: 55-68.

Ray A.K., Ghosh K., Ringo E. 2012 - Enzyme-producing bacteria isolated from fish gut - A review - Aquac. Nutr. 18: 465-492.

Rojas M., Conway P.L. 1996 - Colonization by lactobacilli of piglet small intestinal mucus - J. Appl. Bacteriol. 81: 474-480.

Sahoo P.K., Mukherjee S.C., Sahoo S.K. 1998 - Aeromonas hydrophila versus Edwardsiella tarda: a pathoanatomical study in Clarias batrachus - J. Aquacult. 6: 57-66.

Salvadori L., Gioia D.D., Fava F., Barberio C. 2006 - Degradation of low-ethoxylated nonylphenols by a Stenotrophomonas strain and development of new phylogenetic probes for Stenotrophomonas spp detection - Curr. Microbiol. 52: 13-20.

Sansawat A., Thirabunyanon M. 2009 - Anti-Aeromonas hydrophila activity and characterisation of novel probiotic strains of Bacillus subtilis isolated from the gastrointestinal tract of giant freshwater prawns - Maejo. Int. J. Sci. Technol. 3: 77-87.

Savage D.C. 1992 - Growth phase cellular hydrophobicity and adhesion in vitro of Lactobacilli colonizing the keratinizing gastric epithelium in the mouse - Appl. Environ. Microbiol. 58: 1992-1995.

Siwicki A.K., Anderson D.P., Rumsey G.L. 1994 - Dietary intake of immunostimulants by rainbow trout affects non-specific immunity and protection against furuncuclosis - Vet. Immunol. Immunopathol. 41: 125-139.

Vine N.G., Leukes W.D., Kaiser H., Daya S., Baxter J., Hecht T. 2004 - Competition for attachment of aquaculture candidate probiotic and pathogenic bacteria on fish intestinal mucus - J. Fish. Dis. 27: 319-326.

Zhu H., Qu F., Zhu L.H. 1993 - Isolation of genomic DNAs from plants, fungi and bacteria using benzyl chloride Nucleic Acids Res. 21: 5279-5280. 